\title{
Omfanget av seksuelle krenkelser og overgrep i en norsk ungdomsbefolkning
}

\author{
Svein Mossige og Lihong Huang \\ Norsk institutt for forskning om oppvekst, velferd og aldring (NOVA), Postboks 3223 Elisenberg, 0208 Oslo \\ sveinmos@psykologi.uio.no
}

ENGLISH ABSTRACT

Mossige S, Huang L. The prevalence of sexual offences and abuse within a Norwegian youth population. Nor J Epidemiol 2010; 20 (1): 53-62.

The aim of this cross-sectional school-based study is to present and discuss the prevalence of sexual abuse within a Norwegian population of young people at the age of 18. Contrary to some earlier Norwegian studies the response rate is fairly high and sexually abuse is more clearly defined. The results are compared with an earlier Norwegian study. A clear gendered pattern can be seen in the data: about a quarter of the young correspondents have experienced sexual offenses, among them 77 percent are girls while 90 per cent of the offenders are males. The same pattern appears in other Nordic studies. Most of the reported sexual offenses towards girls take place when they are in their early teens and the offender is usually a boy some years older, in his teens or early twenties. A sexually offended girl reports more often the use of force or physical violence during the event than an offended boy does. The family is an arena with relatively fewer reported cases of sexually abuse or offences in this study than those of earlier research. We cannot say if this implies a decrease of sexual abuse within the family in Norway but international studies indicate such a tendency in some western countries. To be able to see how the picture of sexual abuse develops in society across time, for instance in a youth population, well prepared prevalence studies should be done within regular time-intervals.

\section{INNLEDNING}

I denne artikkelen vil vi presentere og diskutere omfanget av seksuelle krenkelser og overgrep i en norsk ungdomsbefolkning. Hensikten med studien vi baserer oss på var bl.a. å måle omfanget av seksuelle overgrep $i$ en avgrenset og klart definert populasjon hvor vi anvendte operasjonaliserte beskrivelser av det fenomenet som vi ville måle omfanget av og hvor gjennomføringen av undersøkelsen var skolebasert.

Tidligere omfangsundersøkelser gjennomført i Norge er belemret med en del svakheter. Noen baserer seg på utvalg som skal representere et tverrsnitt av befolkningen. For en del av informantene i slike undersøkelser ligger overgrepshendelsene så langt tilbake $\mathrm{i}$ tid at det kan være grunn til å spørre om hvor mye informantene husker av hendelsene (Hardt og Rutter, 2004). I noen studier har man anvendt begrepet seksuelle overgrep uten at dette er klart definert. Informantene i noen studier har svart postalt og svarprosenten er derfor lav. Både manglende begrepsavklaring og lav svarprosent er egnet til å så tvil om reliabiliteten ved det som måles.

I den første omfangsundersøkelsen i Norge (Sætre et al., 1986) bestod utvalget av informanter av et tverrsnitt av befolkningen over 15 år. Disse besvarte et tilsendt spørreskjema og returnerte dette via posten. Her svarte 14 prosent av mennene og 19 prosent av kvinnene at de hadde vært utsatt for minst ett seksuelt overgrep før 18-års alder. Dette omfatter en rekke forskjellige former for overgrep. Svakhetene ved undersøkelsen er mangelfull definering av hva overgrep er, en lav svarprosent (48 prosent) og at utvalget bestod av personer fra 15 år og eldre (ingen øvre aldersgrense). Den lave svarprosenten gjør at det blir få personer i hver kategori når man fordeler på kjønn og aldersgrupper. Et relativt stort frafall skaper usikkerhet ved tolkningen av data. Selv forholdsvis store undergrupper blir små som grunnlag for statistiske analyser. I en annen tilsvarende postal undersøkelse (Tambs, 1994) var svarprosenten så lav som 37 prosent og dette gjør tolkningen av resultatene usikker. Vi kan ikke med sikkerhet vite hvem som er i frafallsgruppen og hvem som svarer.

I løpet av 2000-2001 gjennomførte Folkehelsa spørreskjemaundersøkelsen "Ung Hubro" hvor 15930 ungdommer i alderen 15 til 16 år fra seks forskjellige fylker deltok. Dette dreide seg i utgangspunktet om en helseundersøkelse, men inkluderte ett spørsmål om erfaringer med vold og ett om erfaringer med seksuelle overgrep (Schou et al., 2007). Men vi vet ikke hva slags hendelse volden eller overgrepet handlet om.

I 2004 gjennomførte vi ved NOVA en omfangsundersøkelse av seksuelle overgrep hvor 4911 norske ungdommer mellom 17 til 19 år rekruttert fra 41 videregående skoler deltok. Utvalget var sammensatt av 2878 jenter og 2033 gutter. Svarprosenten var 82. De fleste av de 18 prosent som ikke deltok var fraværende fra skolen på de tidspunkt undersøkelsen ble gjennomført. Denne undersøkelsen vil bli omtalt som 2004studien. Undersøkelsen var en del av en internasjonal studie av overgrepserfaringer blant ungdom i fem Nordeuropeiske land (Mossige et al., 2007), og omfat- 
tet bortimot 20.000 informanter. Spørsmålene vi stilte om seksuelle overgrep ble gjentatt i en ny norsk omfangsundersøkelse blant informanter i samme aldersgruppe i 2007 (Mossige og Stefansen, 2007). Utvalget i 2007-studien omfattet et landsrepresentativt utvalg av 7033 ungdommer fra 3. klassetrinn i videregående skole $\mathrm{i}$ alderen rundt 18 år rekruttert fra 67 videregående skoler over hele landet. Utvalgstrekkingen ble foretatt av Statistisk sentralbyrå. Svarprosenten var 77 prosent. Undersøkelsen omfattet også spørsmål om vold og vitne til vold mot egne foreldre. Det er først og fremst resultater fra denne undersøkelsen, omtalt som 2007studien, vi vil presentere her. Fordi utvalgene er tilsvarende og spørsmålene om overgrep de samme kan vi sammenligne resultater fra 2004-studien med tilsvarende resultater fra 2007-studien. Utvalget i 2007studien er representativt for den delen av den involverte aldersgruppen som er elever ved videregående skoler. Yrkesfaglig studieretning er imidlertid noe underrepresentert $\mathrm{i}$ forhold til allmennfaglig studieretning. Andelen jenter og gutter i utvalget utgjør henholdsvis 58 og 42 prosent. Frafallet av elever er dessuten høyere i 3. klasse enn det vil være på første klassetrinn. Det er en viss sannsynlighet for at det blant dem som har falt fra vil være en større grad av overgrepserfaringer enn blant dem som deltar i undersøkelsen. Alle disse forholdene svekker representativiteten ved utvalget.

\section{KARTLEGGING AV SEKSUELLE KRENKELSER}

Seksuelle overgrep kan omfatte forskjellige hendelser og erfaringer. Hendelsene kan oppfattes som mer eller mindre alvorlige av offeret selv, av utøveren, av rettsvesenet og av andre. Alvorlighetsgraden vil være knyttet til hva den seksuelle handlingen gikk ut på, fra blotting til ulike former for inntrengning, til aldersforskjellen mellom de involverte, til relasjonen mellom offer og overgriper, og til konsekvensene av hendelsen (Mullen et al., 1996; Banyard et al., 2004; Gilbert et al., 2009). Noen definisjoner av seksuelle overgrep baserer seg på at det skal være en klar aldersforskjell mellom overgriper og offer (Leitenberg et al., 1992). I 2004- og i 2007-studien registrerer vi både offerets og overgripers alder, men liten aldersforskjell var ikke et eksklusjonskriterium.

Opplevelsen av hendelsen kan påvirkes av en rekke forhold som overgripers kjønn, nærhet til overgriper, grad av tvang og den utsattes og overgripers alder (Miller et al., 1997; Smith et al., 2000; Mannon og Leitschuh, 2002, s. 150). Spørsmålene i vår undersøkelse som skal fange opp overgrepserfaringer ivaretar hver av disse dimensjonene, uavhengig av hverandre. Spørreskjemaet gir informantene mulighet til å rapportere om erfaringer i forhold til hva som skjedde, hvem som var overgriper og opplevelse av tvang eller frivillighet. Vi bruker formuleringen "Spørsmål om uønskede seksuelle hendelser" og ikke begrepet "seksuelle overgrep" når temaet introduseres i spørreskjemaet.
Denne relativt vide formuleringen benyttes fordi vi ønsker å fange et spekter av hendelser som kan oppleves som krenkende eller som overgrep, men ikke nødvendigvis av alle som har erfart å bli utsatt for seksuelle handlinger mot sin vilje. Dette er bakgrunnen for at vi bruker betegnelsen "uønskede seksuelle hendelser" når vi fremstiller funn i denne teksten. Alternativt kunne vi først spurt om informantene har opplevd ulike seksuelle hendelser og deretter stilt spørsmål om noen av disse ble opplevd som uønskede eller som overgrep. En slik fremgangsmåte kan være problematisk fordi den gjør det vanskelig for informanten å identifisere hvilken hendelse som var uønsket i forhold til hvilke som ikke var det. Vi ønsket å kartlegge omfanget av seksuelle hendelser som informantene opplevde som uønskede. Den valgte spørsmålsformulering er i tråd med dette. Spørsmålene som brukes for å kartlegge erfaringer med seksuelle overgrep er anvendt i tidligere studier som Edgardh (2001) og Svedin og Priebe (2004).

Overgrep kan defineres ut fra hva som i strafferettslig forstand regnes som seksuelle overgrep mot barn. I Norge er den seksuelle lavalder 16 år. Strafferettslig vil seksuelle handlinger som finner sted mellom to individer som er klart under og over den seksuelle lavalder kvalifisere som et overgrep. Men det som er ulovlig vil ikke nødvendigvis oppleves som et overgrep og heller ikke ha skadelige konsekvenser der hvor det er grunn til å anta at handlingen er basert på en gjensidighet mellom de involverte. I spørreskjemaet kartlegger vi først omfanget av enhver uønsket seksuell hendelse blant informantene. Så stilles flere spørsmål om den første og den siste uønskede hendelsen. I fremstillingen av noen av resultatene følger vi denne inndelingen i første og siste uønskede hendelse.

\section{Resultater}

\section{Omfang av ulike former for uonskede seksuelle hendelser}

Tabell 1 gir en oversikt over omfanget av uønskede seksuelle hendelser. Når ikke annet er sagt er det resultater fra 2007-studien som presenteres. Vi kartla om disse hendelsene hadde funnet sted før og etter fylte 13 år. Antallet informanter som rapporterte om uønskede seksuelle hendelser før fylte 13 år var så lavt at vi valgte å slå de to gruppene sammen til én. I tabell 1 presenterer vi derfor det samlede antallet rapporterte uønskede seksuelle hendelser både før og etter fylte 13 år. Kategoriene er ikke gjensidig utelukkende. Noen kan ha erfart flere typer krenkelser, for eksempel både beføling og samleie mot sin vilje. At få har oppgitt uønskede seksuelle hendelser før fylte 13 år, er et interessant funn i seg selv. Det kan tolkes på minst to forskjellige måter. En er at ungdommene har glemt hendelser som fant sted før fylte 13 år. En annen er at det særlig etter fylte 13 hvor ungdom er i ferd med å bli seksuelt aktive at seksuelle krenkelser og overgrep finner sted. 
Tabell 1. Erfaringer med uønskede seksuelle hendelser etter kjønn*.

\begin{tabular}{lccc}
\hline & Totalt (\%) & Jenter (\%) & Gutter (\%) \\
\hline Basistall & $6934(100)$ & $4052(58,4)$ & $2882(41,6)$ \\
**Noen har blottet seg for deg & $857(12,3)$ & $662(16,3)$ & $191(6,6)$ \\
**Noen har befølt deg & $1129(16,3)$ & $915(22,6)$ & $214(7,4)$ \\
Du har befølt deg selv foran noen & $185(2,7)$ & $112(2,8)$ & $73(2,5)$ \\
**Du har befølt en annen & $449(6,5)$ & $302(7,5)$ & $147(5,1)$ \\
Du har måttet onanere mens andre så på & $155(2,2)$ & $79(1,9)$ & $76(2,6)$ \\
**Du har hatt samleie & $676(9,7)$ & $488(12,0)$ & $188(6,5)$ \\
**Du har hatt oralsex & $478(6,9)$ & $312(7,7)$ & $166(5,8)$ \\
**Du har hatt analsex & $144(2,1)$ & $100(2,5)$ & $44(1.5)$ \\
Du har hatt annen form for sex & $191(2,8)$ & $124(3,1)$ & $67(2.3)$ \\
**Du har en eller flere erfaringer i listen & $1869(26,8)$ & $1441(35,6)$ & $418(22,5)$ \\
\hline
\end{tabular}

* Totalt er det 6979 tilfeller. 45 tilfeller som har ikke svart på kjønn er behandlet som missing. Flere og inkonsistente avkrysninger i uønskede hendelser er behandlet som ' $0=$ ikke noen hendelse'.

$* * \mathrm{p}<0,01$

Tabell 3. Erfaringer med voldtektsforsøk eller voldtekt etter kjønn*.

\begin{tabular}{|c|c|c|c|}
\hline & Totalt $(\%)$ & Jenter $(\%)$ & Gutter $(\%)$ \\
\hline Basistall & $6934(100)$ & $4052(58,4)$ & $2882(41,6)$ \\
\hline **Du har vært utsatt for voldtektsforsøk & $305(4,4)$ & $286(7,1)$ & $19(0,7)$ \\
\hline **Du har vært utsatt for voldtekt & $186(2,7)$ & $175(4,3)$ & $11(0,4)$ \\
\hline **Du har vært utsatt for voldtekt og/eller for voldtektsforsøk & $389(5,6)$ & $366(9,0)$ & $23(0,8)$ \\
\hline
\end{tabular}

* Totalt er det 6979 tilfeller. 45 tilfeller som har ikke svart på kjønn er behandlet som missing. flerkrysset i uønskede hendelser er behandlet som ' $0=i k k e$ noe hendelse'.

$* * \mathrm{p}<0,01$

Det er et tydelig kjønnet mønster i forekomsten av seksuelle krenkelser: Alle former for uønskede seksuelle hendelser, bortsett fra å måtte onanere eller beføle seg selv mens andre så på blir rapportert av en signifikant større andel jenter enn gutter. I tabell 1 har vi merket av de typene krenkelser der vi fant signifikante kjønnsforskjeller.

I 2004-studien (Mossige og Abrahamsen 2007) var omfanget av blotting høyere enn det vi fant i 2007studien, mens omfanget av alle former for såkalt penetrerende seksuelle overgrep, samleie, oralsex og analsex, er forholdsvis sammenfallende for begge kjønn $\mathrm{i}$ de to studiene (tabell 2).

Sammenfallet i resultater for penetrerende seksuelle overgrep gir en viss støtte til at omfangstallene er troverdige for de aldersgrupper de omfatter. Det er liten grunn til å anta at de handlinger som det spørres om vil oppfattes ulikt av informantene $i$ de to utvalgene.

\section{Omfang av voldtektsforsok og voldtekt}

Som det går fram av tabell 3 oppga sju prosent av alle jentene at de hadde vært utsatt for voldtektsforsøk mens fire prosent rapporterte å ha vært utsatt for voldtekt. Tallene innebærer at ni prosent av alle jentene $\mathrm{i}$ utvalget har vært utsatt for voldtektsforsøk og/eller voldtekt. Jenter rapporterte både om voldtekt og vold- tektsforsøk ti ganger så ofte som gutter. Tallene er i tråd med resultater fra norsk forskning blant voksne (Pape og Stefansen 2004) og internasjonal forskning på ungdommer selv om størrelsen på kjønnsforskjellen kan variere noe fra studie til studie (Tolin og Foa, 2006).

I Pape og Stefansens (2004) studie av vold i den voksne befolkningen i Oslo (aldersgruppe 24-55 år) hadde ni prosent av kvinnene vært utsatt for voldtektsforsøk mens fem prosent rapporterte om å ha vært utsatt for voldtekt. Blant menn som deltok i denne studien var andelen som rapporterte om tilsvarende typer krenkelser rundt én prosent.

Tabell 2. Erfaringer med uønskede seksuelle hendelser etter kjønn i 2004 og 2007. Prosent.

\begin{tabular}{lcccc}
\hline & \multicolumn{2}{c}{$\begin{array}{c}\text { 2007 studien } \\
(\mathrm{n}=6934)\end{array}$} & \multicolumn{2}{c}{$\begin{array}{c}\text { 2004 studien } \\
(\mathrm{n}=4911)\end{array}$} \\
\cline { 2 - 5 } & Jenter & Gutter & Jenter & Gutter \\
\hline Basistall & 4052 & 2882 & & \\
Noen har blottet seg for deg & 16 & 7 & 22 & 15 \\
Du har hatt samleie & 12 & 7 & 10 & 6 \\
Du har hatt oralsex & 8 & 6 & 7 & 7 \\
Du har hatt analsex & 3 & 2 & 4 & 3 \\
\hline
\end{tabular}


Tabell 4. Erfaringer med milde og grove overgrep etter kjønn*

\begin{tabular}{|c|c|c|c|}
\hline & Totalt $(\%)$ & Jenter $(\%)$ & Gutter $(\%)$ \\
\hline Basistall & $6934(100)$ & $4052(58,4)$ & $2882(41,6)$ \\
\hline **Milde seksuelle krenkelser & $1218(17,6)$ & $955(23,6)$ & $263(9,1)$ \\
\hline **Grove seksuelle krenkelser inkludert voldtekt/voldtektsforsøk & $945(13,6)$ & $708(17,5)$ & $237(8,2)$ \\
\hline **Milde og/eller grove seksuelle krenkelser & $1493(21,5)$ & $1154(28,5)$ & $339(11,8)$ \\
\hline
\end{tabular}

Tabell 5. Kjønn på offer og utøver - første gang det skjedde i vår studie og i den tidligere studien (Antall og prosent).

\begin{tabular}{lcccc}
\hline & \multicolumn{2}{c}{ 2007-studien, Utsatt $\mathrm{n}(\%)$} & \multicolumn{2}{c}{ 2004-studien, Utsatt $\mathrm{n}(\%)$} \\
\cline { 2 - 5 } & Jenter & Gutter* & Jenter & Gutter \\
\hline Utøveren var en mann/gutt & $1105(99)$ & $84(47)$ & $875(99)$ & $53(32)$ \\
Utøveren var en kvinne/jente & $11(1)$ & $95(53)$ & $9(1)$ & $113(68)$ \\
Totalt $(\mathrm{N})$ & $1116(100)$ & $179(100)$ & $884(100)$ & $166(100)$ \\
\hline
\end{tabular}

* I 10 tilfeller under gutt som offer i 2007-studien var det flere avkryssinger som er behandlet som missing.

\section{Fordeling av milde og grove seksuelle krenkelser på gutter og jenter}

For å få et bilde av summen av grove og milde seksuelle krenkelser fordelt etter kjønn, slo vi sammen disse hendelsene $\mathrm{i}$ to grupper og utelukket blotting: Milde bestod av alle uønskede seksuelle hendelser som dreide seg om beføling og onanering. Grove bestod av alle andre former for uønsket sex inkludert voldtekt og voldtektsfors $ø$ k. 23,6 prosent av jentene hadde opplevd milde seksuelle krenkelser mens ni prosent av guttene rapporterte om det samme. 17 prosent av jentene rapporterte om grove seksuelle krenkelser. Det tilsvarende tall for guttene var åtte prosent (tabell 4). Forskjellene mellom jenter og gutter er tydelige og signifikante $(\mathrm{p}<0.01)$ for alle tre hovedkategorier av seksuelle krenkelser.

Tabell 4 viser at 1154 jenter og 339 gutter hadde vært utsatt for minst en form av seksuelle krenkelser. Av de som rapporterte om minst en form for seksuell krenkelse eller overgrep var 77,3 prosent jenter mens altså 22,7 prosent var gutter. Tilsvarende tall fra 2004studien var henholdsvis 84 og 16 prosent.

\section{Andel som rapporterer om flere erfaringer med seksuelle krenkelser eller erfaringer med både seksuelle krenkelser og vold}

Konsekvenser av vold og overgrep blir gjerne mer alvorlige der den utsatte har opplevd flere slike hendelser (Briere og Elliott, 2003). Vi kartla derfor i hvilken grad informantene rapporterte om flere tilfeller av seksuelle krenkelser. Jenters utsatthet for seksuelle krenkelser kommer tydelig frem gjennom hvordan hyppighet av slike hendelser fordeler seg på kjønn: Mer enn 24 prosent av jentene hadde vært utsatt for en til tre seksuelle krenkelser. Det tilsvarende tallet for gutter var i overkant av ni prosent. Mer enn seks prosent av jentene hadde vært utsatt for fire eller flere krenkelser. Blant guttene rapporterte litt over tre prosent at de hadde vært utsatt for fire seksuelle krenkelser eller flere.

\section{Kjonn på offer og utover ved forste uonskede seksuelle hendelse}

Tallene her refererer til en serie spørsmål i spørreskjemaet som omhandlet den "første" uønskede seksuelle hendelsen. Betegnelsen første kan gi inntrykk av at det finnes flere hendelser (andre, tredje). Dette er ikke nødvendigvis tilfelle. Vi har beholdt betegnelsen "første" fordi den er i tråd med måten spørsmålene ble stilt på i spørreskjemaet.

Det er 1295 tilfeller som har gitt informasjon om overgriper (tabell 5). Av de 179 guttene som svarte at de var blitt utsatt for en uønsket seksuell handling, dreide 95 av tilfellene seg om at overgriper var en kvinne/jente mens det var en mann/gutt i 84 av tilfellene. For utsatte gutter var kjønnsfordelingen blant overgriperne nærmest 50/50. Jenter rapporterte om mannlige utøvere i omtrent 99 prosent av tilfellene. Kvinner/jenter som utsetter andre jenter for uønskede seksuelle hendelser er med andre ord et sjeldent fenomen. Totalt ble det rapportert om at en mann/gutt var utøver av den uønskede seksuelle handlingen i over 90 prosent av tilfellene mens en kvinne/jente var utøver $\mathrm{i}$ under 10 prosent av tilfellene.

Den prosentvise fordelingen av mannlige og kvinnelige forøvere $\mathrm{i}$ forhold til utsatte gutter og jenter var svært lik i 2004- og i 2007-studien, særlig i forhold til jenter som ofre: I begge studiene var utøveren en gutt/ mann i 99 prosent av tilfellene. Det var noe større forskjell mellom studiene i hvor stor andel av overgriper- 
Tabell 6. Jentas alder da det skjedde etter overgripers alder ved første hendelse. (Antall og prosent).

\begin{tabular}{lcccccc}
\hline & & \multicolumn{4}{c}{ Overgripers alder } \\
\cline { 3 - 7 } & Antall jenter & Yngre enn & & & & 25 eller \\
Jentas alder da det skjedde & $\mathrm{n}(\%)$ & 10 år & $10-14$ år & $15-19$ år & $20-24$ år & eldre \\
\hline Totalt i overgriperne $\mathrm{n}(\%)$ & & $36(3)$ & $130(11)$ & $410(33)$ & $165(13)$ & $486(40)$ \\
Yngre enn 10 år & $203(17)$ & 92 & 30 & 6 & 1 & 22 \\
Mellom 10 og 14 år & $434(35)$ & 8 & 66 & 24 & 22 & 44 \\
Etter fylte 15 år & $590(48)$ & 0 & 1 & 70 & 77 & 34 \\
Totalt & $1227(100)$ & 100 & 100 & 100 & 100 & 100 \\
\hline
\end{tabular}

ne som var en gutt/mann eller jente/kvinne der hvor den utsatte var en gutt, men i begge studiene rapporterer flertallet av de utsatte guttene om en jente/kvinne som overgriper.

Bildet av at jenter nesten utelukkende utsettes for uønskede seksuelle hendelser fra en gutt eller mann er i overensstemmelse med resultater fra andre internasjonale studier. En amerikansk studie (Briere og Elliot, 2003) viser for eksempel at 93 prosent av de kvinnelige ofrene var utsatt fra en gutt/mann. I denne studien var imidlertid flertallet av utøverne av uønsket sex overfor gutter også en gutt eller mann. 70 prosent av utsatte gutter/menn var utsatt fra en mannlig utøver. Samtidig rapporterte 39 prosent av de utsatte mennene at de også hadde vært utsatt for en uønsket seksuell hendelse fra en kvinne. I våre to studier fra 2007 og 2004 finner vi altså det motsatte forholdet: flertallet av utsatte gutter rapporterer om en jente/kvinne som utøver.

Denne forskjellen kan bero på ulikheter i de undersøkte utvalg. Men forskjellen kan også avspeile endringer over tid i deler av overgriper/offer bildet. I studien til Sætre et al. (1986) rapporterte 93 prosent av de kvinnelige ofrene om en gutt/mann som utøver. Andelen av kvinnelige overgripere i forhold til kvinner som offer er klart lavere i vår undersøkelse. I Holter et als undersøkelse (1986) rapporterte bare 19 prosent av mennene om en jente/kvinne som overgriper mens vi finner at mer enn 50 prosent av de utsatte mennene oppgav en kvinne som overgriper. Forskjellen kan være uttrykk for at faktisk forholdsvis flere kvinner er overgripere overfor menn enn hva tilfellet var for noen år siden. En annen mulig forklaring er at terskelen for menn til å rapportere om slike forhold er blitt lavere, altså at menn i større grad enn for noen år siden definerer noen seksuelle hendelser som uønskede og at noen av disse tolkes som et overgrep.

\section{Kjonns- og alderskonstellasjoner mellom offer og utover (forste hendelse)}

Hvilke konstellasjoner er vanligst når det gjelder alder på overgriper og på offer der offeret er en jente? Det er 1227 jenter som har gitt informasjon om sin alder og overgripers alder ved første hendelse. Vi fordelte de utsatte jentene i tre alderskategorier: Yngre enn 10 år, fra 10 til 14 år; og fra 15 til 18 år. Utøverne av de uøn- skede seksuelle handlingene ble plassert i tilsvarende alderskategorier, samt ytterligere to kategorier: fra 20 til 24 år og 25 år eller eldre. Antall og andel av utøvere og utsatte fordelt på disse aldersgruppene er satt opp i tabell 6 .

I 2004-studien var den vanligste utøver/offer konstellasjonen en jente $i$ alderen 10-14 år som krenkes av en gutt i alderen 15-19 år. I 2007-studien var 35 prosent av de utsatte jentene i alderen 10-14 år forste gang de opplevde en uønsket seksuell hendelse mens 48 prosent av de utsatte jentene var i alderen 15-18 år (tabell 6). Det betyr at mer enn 83 prosent av de utsatte jentene opplevde første uønskede seksuelle hendelse i løpet av tidlig eller middel ungdomstid. Vi finner altså et mønster når det gjelder alder på den utsatte som er sammenfallende i de to studiene.

En stor andel av slike handlinger utøves av gutter som befinner seg innenfor samme aldersgruppering: 44 prosent av de utsatte jentene rapporterte om en utøver som selv var i tenårene. Et liknende tall fant vi også $i$ 2004-studien (Abrahamsen og Mossige, 2007, s.112). Her var 46,2 prosent av jentene utsatt for en uønsket seksuell handling fra en gutt som også var tenåring. Andelen av jenter som utsettes for uønskede seksuelle hendelser fra en person som er 20 eller eldre var i begge undersøkelsene 53 prosent. Andelen av utøvere fra 25 år og oppover er litt større i 2007 studien og det samme gjelder andelen av utsatte jenter i alderen 15-18 år, mens andelen av utsatte jenter fordelt på de ulike alderskategorier av overgripere er forholdsvis sammenfallende mellom de to studiene. Konklusjonen er at mange jenter utsettes for uønskede seksuelle handlinger fra andre tenåringer, men at en enda større gruppe utsettes for slike handlinger fra personer fra 20 år og oppover.

Tabell 6 viser at 70 prosent av krenkerne i aldersgruppen 15-19 år utførte en seksuell krenkelse mot en jente på 15-18 år. 24 prosent av krenkerne i den samme aldersgruppen gjorde en seksuell krenkelse mot en jente på 10-14 år. Det betyr at 94 prosent av de mannlige utøverne i alderen 15-19 år utførte en seksuell krenkelse mot en jente mellom 10-18 år. Men dette mønsteret gjelder ikke hele bildet av konstellasjoner mellom utøver og offer. En relativt stor andel av noe eldre utøvere begår en seksuell krenkelse mot jenter som er betydelig yngre enn dem selv. Av mannlige 
krenkere som var 25 år eller eldre utførte 44 prosent en seksuell krenkelse mot en jente i alderen 10-14 år. Av de som har vært utsatt for seksuelle krenkelser rapporterer $632(51 \%)$ at overgriper er minst fem år eldere enn dem selv.

Det er få internasjonale studier som har gjort en tilsvarende detaljert undersøkelse av alderskonstellasjonen mellom utøver og utsatt hvor de utsatte tilhører en ungdomsbefolkning. En dansk omfangsundersøkelse av 15-16 åringer gjennomført i $2002 \quad(\mathrm{~N}=5829)$ (Helweg-Larsen og Bøving Larsen, 2006) ga en fordeling av de rapporterte overgriperne mht. alder som var noe annerledes enn den vi fant: 59 prosent av de seksuelle krenkelsene ble utført av en person som var mellom 15 og 17 år mens altså de øvrige 41 prosent av de seksuelle krenkelsene ble utført av personer som var 18 år eller eldre. Tallene er ikke kommentert i den danske undersøkelsen. Sannsynligvis kan den høye andel av seksuelle krenkelser utført av personer mellom 15 og 17 år forklares med at man i den danske undersøkelsen registrerte enhver seksuell handling som informantene i aldersgruppen opp til og med 14 år hadde rapportert, hvor utøveren var mellom 15 til 17 år, som et overgrep. I følge dansk lov er en slik handling ulovlig og i den forstand et seksuelt overgrep. I vår undersøkelse stilte vi i utgangspunktet spørsmål om informantene hadde opplevd en ufrivillig og uønsket seksuell handling. Hvis de hadde opplevd en slik handling stilte vi deretter spørsmål om alderen på den som gjorde dette første gang det skjedde. I følge norsk lov er det ikke straffbart at to personer har sex med hverandre når begge har en alder rundt seksuell lavalder, selv om den ene er litt under og den andre litt over når begge gir sitt samtykke (NOU, 1997:23, s. 22). Den seksuelle lavalder er 15 år i Danmark og 16 år i Norge. I begge undersøkelser ser vi det samme bildet: Mange av de seksuelle krenkelsene utøves av en gutt som selv er i tenårene.

\section{Siste uonskede seksuelle hendelse - hvem utforte handlingen?}

Mønsteret vi har beskrevet i det foregående baserer seg på hva informantene svarer på spørsmål om første uønskede hendelse. Men mønsteret gjentas i informantenes svar på spørsmål om siste uønskede seksuelle hendelse: Det er 441 informanter som svarer på dette spørsmålet, 374 jenter eller 9,3 prosent av hele utvalget av jenter og 67 menn eller 2,3 prosent av hele utvalget av gutter (tabell 7). I forhold til jenter var den som utførte den uønskede seksuelle handlingen en gutt

Tabell 7. Kjønn på offer og utøver - siste gang det skjedde. Prosent.

\begin{tabular}{lcc}
\hline & $\begin{array}{c}\text { Jenter } \\
(\mathrm{n}=374)\end{array}$ & $\begin{array}{c}\text { Gutter } \\
(\mathrm{n}=67)\end{array}$ \\
\hline Utøveren var en mann/gutt & 99 & 40 \\
Utøveren var en kvinne/jente & 1 & 60 \\
\hline
\end{tabular}

eller mann i 99 prosent av tilfellene - som ved den første seksuelle hendelsen. I forhold til guttene var utøveren en kvinne i 60 prosent av tilfellene og altså en mann i 40 prosent av tilfellene. Utøverens kjønn i forhold til utsatte gutter er også ganske sammenfallende med den fordeling som vi fant ved første seksuelle hendelsen.

Dette sammenfallet i fordeling av utøvers kjønn ved første og siste seksuelle hendelse indikerer et mønster hvor fordelingen mellom utsatte synes å være om lag 80 prosent jenter og 20 prosent gutter, hvor utøveren i forhold til jenter nesten utelukkende er en gutt eller mann, mens utøveren i forhold til gutter er en kvinne/ jente i 50-60 prosent av tilfellene og en gutt/mann i 4050 prosent av tilfellene, og hvor utøveren er en gutt eller mann i om lag 90 prosent av alle tilfeller av overgrep og en jente eller kvinne i 10 prosent av tilfellene.

\section{Hvem var utoveren ved forste uonskede seksuelle hendelse?}

På spørsmål om hvem som utøvde den uønskede seksuelle hendelsen, forste gang den skjedde valgte informantene blant svaralternativer som dekket de fleste tenkbare muligheter. Ikke alle som rapporterte om uønskede seksuelle hendelser svarte på spørsmålet om hvem som var utøver. Derfor blir det få i hver svarkategori. Vi slo sammen alle svaralternativer i fem kategorier, en kategori som omfattet alle nære familiemedlemmer hvor den seksuelle handlingen er av incestuøs karakter, en kategori som omfattet venner og bekjente, en for steforeldre og andre slektninger, en kategori for fremmede, og en kategori for personer som møtte barnet eller ungdommen først og fremst i en yrkesmessig sammenheng.

Venner, kjæreste og bekjente er den største gruppen av utøvere og mer enn 10 prosent av alle informanter $i$ undersøkelsen rapporterer om en utøver i denne gruppen (tabell 8). Dette mønsteret finner vi også i internasjonale studier. I en amerikansk studie (Flanagan og Furman, 2000) av kvinnelige studenter med en gjennomsnittsalder på omlag 19 år var for eksempel overgriperen i flertallet av tilfellene en bekjent av offeret. Omlag sju prosent av informantene rapporterte at en fremmed hadde utsatt dem for den uønskede seksuelle handlingen. "Fremmedgruppen" består av personer som er 20 år og eldre. Veldig få av de utsatte jentene og guttene har vært utsatt for seksuelle overgrep fra trener, lærer o.l. Antall jenter og gutter som rapporterte om at utøveren var et nært familiemedlem er få, og utgjør omlag en prosent av alle informanter. Incestuøse seksuelle relasjoner ble rapportert relativt sjelden.

Disse tallene avviker noe fra andre tidligere undersøkelser. I den første norske prevalensundersøkelsen (Sætre et al., 1986) svarte seks prosent av de krenkede at hendelsen ble utført av en foreldrefigur. Det er betydelig høyere enn i vår undersøkelse.

Av alle uønskede seksuelle handlinger var andelen utøvd av en jevnaldrende 49 prosent, mens voksne utenom familie eller slekt stod som utøvere av 10 
Tabell 8. Hvem var personen som gjorde dette? Antall og prosent av alle gutter og alle jenter.

\begin{tabular}{|c|c|c|c|c|c|c|c|}
\hline \multirow{3}{*}{ Basistall } & \multirow{2}{*}{\multicolumn{2}{|c|}{$\begin{array}{c}\text { Gutter } \\
2882 \\
\end{array}$}} & \multirow{2}{*}{\multicolumn{2}{|c|}{$\begin{array}{c}\text { Jenter } \\
4052 \\
\end{array}$}} & \multirow{2}{*}{\multicolumn{3}{|c|}{$\begin{array}{c}\text { Totalt } \\
6934\end{array}$}} \\
\hline & & & & & & & \\
\hline & Antall & $\%$ av basistall & Antall & $\%$ av basistall & Antall & $\%$ av basistall & $\%$ av utøvere \\
\hline Venn, kjæreste, bekjent & 166 & 5,8 & 578 & 14,3 & 744 & 11 & 48,6 \\
\hline Stefar, stemor, annen slektning & 9 & 0,3 & 75 & 1,9 & 84 & 1 & 5,5 \\
\hline Trener, lærer, annen & 43 & 1,5 & 114 & 2,8 & 157 & 2 & 10,3 \\
\hline Totalt & 310 & 4,5 & 1220 & 17,5 & 1530 & 22 & 100 \\
\hline
\end{tabular}

Tabell 9. Var hendelsen frivillig eller skjedde den under tvang etter kjønn. Antall og prosent.

\begin{tabular}{lcc}
\hline & \multicolumn{2}{c}{ Utsagnet passer godt } \\
\cline { 2 - 3 } & Jenter $(\%)$ & Gutter $(\%)$ \\
\hline Basistall for offererfaringer & 1441 & 418 \\
*Var for ung til å forstå & $372(25,8)$ & $64(15,3)$ \\
$\quad$ Deltok frivillig, men angret etterpå & $170(11,8)$ & $37(8,9)$ \\
*Ble lurt & $389(27,0)$ & $58(13,9)$ \\
*Ble overtalt & $293(20,3)$ & $44(10,5)$ \\
*Utsatt for mildt press & $387(26,9)$ & $43(10,3)$ \\
*Utsatt for sterkt press & $331(23,0)$ & $31(7,4)$ \\
*Ble brukt fysisk tvang i form av å bli holdt fast, truet med vold eller slått & $448(31,1)$ & $40(9,6)$ \\
\hline *p<0,01 & &
\end{tabular}

prosent av disse handlingene (tabell 8). Bare en ganske liten andel, under fem prosent, ble utøvd av nære familiemedlemmer. Dette dreier seg om det vi vil betegne som incestuøse handlinger. Fremmede stod som utøvere av bortimot en tredjedel av de uønskede seksuelle handlingene.

Den lave andel av krenkere eller overgripere blant nære familiemedlemmer er i tråd med resultater fra andre nordiske omfangsstudier. Helweg-Larsen og Bøving Larsen (2006) finner i sin danske omfangsstudie at ca en prosent av de undersøkte 15-16 åringene rapporterer om overgrep utøvd av en person i nær familie. Også en finsk studie av far-datter incest (Sariola og Uutela, 1996) fant et omfang av slike uønskede seksuelle hendelser i nære familierelasjoner forenlige med våre funn. Omfanget av seksuelle hendelser mellom datter og biologisk far var bare 0,2 prosent.

Gir disse lave prevalenstallene et dekkende bilde av omfanget av incestuøse seksuelle handlinger? Omfangstallene fra de tre nordiske studiene kan tyde på det. Men vi kan ikke helt utelukke at de lave omfangstallene er uttrykk for en underrapportering: En del studier har vist at seksuelle overgrep hvor utøveren av overgrepet er et nært familiemedlem ikke blir rapportert fordi det utsatte barnet vegrer seg mot å fortelle om hendelsen (Smith et al., 2000). Dette er sensitive opplysninger hvor vi derfor må være forsiktige med å trekke bastante konklusjoner. Men resultatene fra denne studien sett i sammenheng med de to øvrige nordiske studiene, gir støtte til at omfangstall når det gjelder incestuøse seksuelle overgrep er lavere enn det som har fremkommet i tidligere norske undersøkelser.

\section{Var den forste uonskede seksuelle hendelsen frivillig eller skjedde den under tvang?}

De totale omfangstallene vi finner er relativt høye. Kan det være at vi faktisk måler forekomst av noe som skjedde frivillig og dermed vanskelig kan kalles en krenkelse eller overgrep? For å svare på dette ba vi informantene om å vurdere i hvilken grad ni forskjellige karakteriseringer av tvang/frivillighet passet med hvordan de hadde opplevd den uønskede seksuelle hendelsen. Disse karakteristikkene var: "Var for ung til å forstå"; "Deltok frivillig, men angret etterpå"; "Jeg ble lurt"; "Jeg ble overfalt"; "Jeg ble utsatt for mildt press"; "Jeg ble utsatt for sterkt press"; "Jeg ble holdt fast"; "Jeg ble truet med vold"; "Jeg ble slått eller skadet". De tre siste kategoriene indikerer bruk av fysisk makt eller trusler om dette. I den videre fremstilling her er de slått sammen til en kategori. For hver av karakteristikkene over kunne informantene krysse av om de "Passer svært godt", "Passer nokså godt", "Passer nokså dårlig", eller "Passer svært dårlig". Karakteristikkene er ikke gjensidig utelukkende.

De aller fleste av de som tidligere hadde svart at de hadde opplevd en uønsket seksuell hendelse besvarte dette spørsmålet og i alt ble det gitt 1441 karakteristikker fra utsatte jenter og 418 karakteristikker av hendelsen fra gutter. Jenter og gutter svarte signifikant forskjellig mht. hvordan de fleste karakteristikkene 
Tabell 10. Var det alkohol med i bildet ved første uønskede seksuelle hendelse etter kjønn. Antall og prosent.

\begin{tabular}{lcccc}
\hline & \multicolumn{2}{c}{ Jenter (\%) } & \multicolumn{2}{c}{ Gutter (\%) } \\
Basistall & \multicolumn{2}{c}{$1441(100)$} & \multicolumn{2}{c}{$418(100)$} \\
\hline & Første gang* & Siste gang** & Første gang* & Siste gang** \\
\cline { 2 - 5 } Ja, både jeg og den/de andre var beruset & $238(16,5)$ & $105(7,3)$ & $50(12,0)$ & $17(4,1)$ \\
Ja, jeg var selv beruset & $59(4,1)$ & $16(1,1)$ & $14(3,3)$ & $3(0,7)$ \\
Ja, den/de andre var beruset & $123(8,5)$ & $42(2,9)$ & $20(4,8)$ & $8(1,9)$ \\
Nei, ikke svarte og flerkryssing & $1021(70,9)$ & $1278(88,7)$ & $334(79,9)$ & $390(93,3)$ \\
\hline
\end{tabular}

*Kjønnsforskjell er signifikant på 0,05-nivå. ** Kjønnsforskjell er signifikant på 0,01-nivå.

passet $(\mathrm{p}<0,01)$ (Tabell 9). 448 eller 31 prosent av jentene som opplevde en uønsket seksuell hendelse rapporterte at det ble brukt fysisk tvang i form av å bli holdt fast, truet med vold eller slått. Dette innebærer at over 10 prosent av alle jentene i undersøkelsen $(\mathrm{N}=4053)$ opplevde minst en uønsket seksuell hendelse hvor det ble brukt en form for fysisk tvang. Det tilsvarende tallet for gutter $(\mathrm{N}=2886)$ var 1,3 prosent.

Ved siden av at uønskede seksuelle hendelser forekommer langt hyppigere blant jenter enn blant gutter rapporterer altså jenter om en betydelig større grad av mer entydige former for tvang enn det utsatte gutter giør. En større andel gutter enn jenter svarer at de mulige karakteristikker av den uønskede seksuelle hendelsen ikke passer. Dette gjelder særlig for de karakteristikker som innebærer en mer entydig tvang. Forskjellen mellom gutters og jenters opplevelse av tvang er minst (ikke signifikant) $i$ forhold til den kategoriseringen som innebærer minst tvang og et aspekt av frivillighet.

\section{Var det alkohol med $i$ bildet ved forste og siste uonskede seksuelle hendelse?}

Vår undersøkelse har vist at en betydelig andel av uønskede seksuelle handlingene foregår mellom individer som er jevnaldrende. Ut fra dette kunne man tenke seg at en del av overgrepene fant sted i sosiale relasjoner hvor det ble brukt alkohol. Tidligere norske studier av ungdom og seksualitet har antydet en slik sammenheng (Pedersen og Skrondal, 1996). Blant alle de 1859 unge med offererfaringer, svarte 27 prosent 'ja' på spørsmålet om det var alkohol med i bildet ved at de selv eller utøver var beruset under den uønskede seksuelle hendelsen første gang den skjedde. Siste gang den uønskede seksuelle hendelsen fant sted svarer 10 prosent 'ja' på spørsmålet om minst en av de involverte var beruset.

Som det fremgår av tabell 10, foregikk flertallet av hendelsene rapportert av jenter (over 70 prosent) uten det var alkohol inne i bildet. Det gjelder både første og siste hendelse. Samtidig er det en klar forskjell mellom jenter og gutter ved at en større andel av utsatte jenter enn utsatte gutter rapporterer om at det var alkohol med i bildet - i tilfeller hvor begge var beruset, den andre var beruset og hvor jenta selv var beruset. Andelen som rapporterer om at alkohol var involvert er også betydelig høyere ved første uønskede seksuelle hendelse enn ved siste - både for jenter og gutter. Selv om flertallet av hendelsene finner sted uten at noen var beruset er beruselse til stede så ofte at det kan være en viktig risikofaktor for at slike hendelser finner sted, særlig for jenter og i forhold til den første overgrepshendelsen.

\section{DISKUSJON}

Funnene i denne undersøkelsen er sammenfallende med flere funn i 2004-studien (Mossige et al., 2007). I begge studiene ser vi et klart kjønnet mønster i funnene: Det store flertallet av utsatte er jenter som blir gjenstand for krenkelser eller overgrep fra en gutt/ mann. I de tilfeller hvor den utsatte er en gutt er jenter/ kvinner i flertall blant krenkerne. Disse overgrepene utgjør altså en ganske liten andel av det totale omfanget av overgrep. Av de former for tvang som kommer til anvendelse er denne mer entydig fysisk $i$ en langt større del av tilfellene når jenter blir utsatt for seksuelle krenkelser og overgrep enn når gutter rapporterer om slike erfaringer.

Vi finner det samme mønsteret i både 2004- og 2007-studien, og det kan tyde på at dette mønsteret er et robust funn. Det samme kjønnede mønsteret har også fremkommet $\mathrm{i}$ andre tidligere norske omfangsstudier som for eksempel i Sætre et al. (1986). Men mønsteret er tydeligere i vår studie. Vi finner det også igjen $\mathrm{i}$ andre nordiske studier: Helweg-Larsen og Bøving Larsen (2006) og Priebe og Svedin (2008) og i internasjonale studier (Fergusson et al., 2008).

Samtidig viser vår studie også at en del gutter utsettes for krenkelser hvor krenkeren er en jente/kvinne. En relativt stor andel gutter rapporterte om uønskede seksuelle hendelser i form av samleie. Hvordan skal man forstå en slik hendelse? Utsatte gutter rapporterer i mindre grad om entydige former for tvang enn jenter, og dette kan tolkes slik at uønskede seksuelle overgrep som samleie for guttenes vedkommende foregikk med mindre grad av ufrivillighet, enn for jentenes vedkommende. En del av disse hendelsene kan dreie seg om at gutten er med på noe som han seinere angrer på, eller at han er med på det delvis mot sin egen vilje. Den relativt store andelen gutter som rapporterer om slike overgrep kan være uttrykk for en økende bevisst- 
gjøring blant gutter om betydningen av gjensidighet $\mathrm{i}$ seksuelle relasjoner. I den grad gjensidighet oppleves som fraværende kan hendelsen tolkes som et overgrep også av gutter.

En betydelig andel av overgrep fant sted mellom utsatt og utøver hvor begge var i tenårene, mens bare én prosent av rapporterte uønskede seksuelle hendelser foregikk hvor utøver var fra den utsattes nære familie. Som vist sammenfaller dette med resultater fra flere nordiske studier (Helweg-Larsen og Bøving Larsen, 2006; Sariola og Uutela, 1996; Hanson et al., 2003; Seto et al., 2010). Hvis terskelen for å rapportere om seksuelle krenkelser innenfor familien har forandret seg skulle vi tro at den var blitt lavere og at flere av incestuøse seksuelle hendelser ble rapportert enn tidligere. Etter all oppmerksomheten som har vært i offentlighet og media om seksuelle overgrep er det ikke rimelig å tro at terskelen er blitt høyere. Det kan også hende at denne oppmerksomheten har hatt en viss effekt ved at omfanget av incestuøse seksuelle overgrep har blitt lavere i løpet av de senere årene. Det ville i så fall være en utvikling som er i tråd med hva bl.a. Jones et al. (2006) har rapportert om på grunnlag av ulike amerikanske omfangsmålinger.

Utvalget $\mathrm{i}$ denne studien er både en styrke og en svakhet. Styrken ligger i at utvalget er omfattende og at det inkluderer vanlig ungdommer. Svakheten ligger i at frafallet av elever i 3. klasse på videregående skole er ganske høyt (opp mot 30 prosent). Frafallet innebærer sannsynligvis at særlig problembelastet ungdom er underrepresentert i utvalget vårt. Hvis dette er tilfellet er våre omfangstall for lave og peker dermed også på at det vil være ønskelig å gjennomføre skolebaserte studier av omfang av seksuelle krenkelser og overgrep i yngre aldersgrupper enn det vi har sett på her. Skolebaserte studier hvor utvalget for eksempel besto av 15til 16-åringer vil sannsynligvis kunne trekke på et bredere og mer representativt utvalg av ungdommer. Samtidig vil noen hendelser $\mathrm{i}$ form av krenkelser og overgrep ligge nærmere $i$ tid.

En utfordring ved fremtidig forskning på temaet seksuelle overgrep og vold er å få til gode kombinasjoner av kvantitative mål på omfang og kvalitative data om noen av de fenomener som vi måler omfanget av. I vår 2007-studie ble informantene bedt om å gi skriftlige svar på noen få åpne spørsmål. Etter å ha svart på kvantitative spørsmål om for eksempel uønskede seksuelle hendelser ble informantene bedt om å beskrive hva som skjedde. Vi fikk så mange som 983 beskrivelser. De aller fleste var ganske korte, men utgjør på tross av dette et interessant, men så langt uutforsket materiale. Å skulle gi et skriftlig svar på slike åpne spørsmål kan oppleves som tidkrevende av informantene. Erfaringer bl.a. fra Danmark (Helweg-Larsen og Bøving Larsen, 2006) viser at elektroniske spørreskjema som besvares via pc gir betydelig mer rom for å kunne gi mer omfattende kvalitative besvarelser. Informantene som i dette tilfellet dreide seg om 15åringer, benyttet seg hyppig av denne muligheten til å svare på åpne spørsmål og deres svar var til dels ganske omfattende.

En grunn til å gjennomføre denne type omgangsundersøkelser er å undersøke om det skjer endringer av omfang over tid. Hvis offentlige innsatser mot seksuelle overgrep skal kunne vurderes behøves målinger av omfang som gjentas med jevne mellomrom med samme type spørsmål og overfor tilsvarende utvalg i befolkningen. Kombinert med den type kvalitative studier som er nevnt over vil slike studier gi et verdifullt datamateriale som kan gi oss indikasjoner på hva slags utviklingsforløp når det gjelder ytringsformer for seksualitet som finner sted for eksempel i en ungdomsbefolkning.

\section{REFERANSER}

Abrahamsen S, Mossige S. Sexual abuse in Norway: Age, risk and attitudes. I: Mossige S, Ainsaar M, Svedin CG (red.). The Baltic Sea Study on Adolescent Sexuality. NOVA rapport 19: Oslo, 2007: 112-120.

Banyard VL, Williams LM, Siegel JA. Childhood sexual abuse: A gender perspective on context and consequences. Child Maltreatment 2004; 9 (3): 223-238.

Briere J, Elliot DM. Prevalence and psychological sequelae of self-reported childhood physical and sexual abuse in a general population sample of men and women. Child Abuse \& Neglect 2003; 27: 1205-1222.

Edgardh K. Adolescent sexuality and sexual abuse. A Swedish perspective. Stockholm: Karolinska Institutet, 2001.

Fergusson DM, Boden JM, Horwood LJ. Exposure to childhood sexual and physical abuse and adjustment in early adulthood. Child Abuse \& Neglect 2008; 32: 607-619.

Flanagan AS, Furman WC. Dating violence through the lens of adolescent romantic relationships. Child Maltreatment 2000; 5: 360-363.

Gilbert R, Widom CS, Browne K, Fergusson D, Webb E, Janson S. Burden and consequences of child maltreatment in high-income countries. Lancet 2009; 373: 68-81.

Hanson RF, Kievit LW, Saunders BE, Smith DW, Kilpatrick DG, Resnick HS, Ruggiero KJ. Correlates of adolescent reports of sexual assault: findings from the national survey of adolescents. Child Maltreatment 2003; 8 (4): 261-272. 
Hardt J, Rutter M. Validity of retrospective reports of adverse childhood experiences: review of the evidence. Journal of Child Psychiatry and Psychology 2004; 45: 260-274.

Helweg-Larsen K, Bøving Larsen $\mathrm{H}$. The prevalence of unwanted and unlawful sexual experiences reported by Danish adolescents: Results from a national youth survey in 2002. Acta Pcediatrica 2006; 95:1270-1276.

Jones LM, Finkelhor D, Halter S. Child Maltreatment Trends in the 1990s: Why does neglect differ from sexual and physical abuse? Child Maltreatment 2006; 1 (2): 107-120.

Leitenberg H, Greenwald E, Cado S. A retrospective study of longterm methods of having been sexually abused during childhood. Child Abuse \& Neglect 1992; 16: 339-407.

Mannon K, Leitschuh G. Child sexual abuse: A review of definitions, instrumentation, and symptomatology. North American Journal of Psychology 2002; 4 (1): 149-160.

Miller R, Dwyer J. Reclaiming the mother-daughter relationship after sexual abuse. Australian and New Zealand Journal of Family Therapy 1997; 18: 194-202.

Miltenburg R, Singer E. The ab(use) of reliving childhood trauma. Theory \& Psychology 1997; 7: 605-628.

Mossige S, Ainsaar M, Svedin CG (red). The Baltic Sea Study on Adolescent Sexuality. NOVA rapport 19: Oslo, 2007.

Mossige S, Stefansen K. Vold og overgrep mot barn og unge: En selvrapporteringsstudie blant avgangselever $i$ videregående skole. NOVA rapport 20: Oslo, 2007.

Mullen PE, Martin JL, Anderson JC, Romans SE, Herbison GP. The long-term impact of the physical, emotional, and sexual abuse of children: A community study. Child Abuse \& Neglect 1996; 20 (1): 7-21.

NOU 23. Seksuallovbrudd. Straffelovens delutredning VI. Statens Forvaltningstjeneste. Oslo, 1997.

Pape H, Stefansen K. Den skjulte volden? En undersøkelse av Oslobefolkningens utsatthet for trusler, vold og seksuelle overgrep. NKVTS, rapport nr.1/04: Oslo, 2004.

Pedersen W, Skrondal A. Alcohol and sexual victimization: A longitudinal study of Norwegian girls. Addiction 1996; 96 (4): 565-581.

Priebe G, Svedin CG. Child sexual abuse is largely hidden from the adult society. An epidemiological study of adolescents' disclosures. Child Abuse \& Neglect 2008; 32: 1095-1108.

Sariola H, Uutela A. The prevalence and context of incest abuse in Finland. Child Abuse \& Neglect 1996; 20 (9): 843-850.

Schou L, Dyb G, Graff-Iversen S. Voldsutsatt ungdom i Norge: Resultater fra Helseundersøkelser i seks fylker. Folkehelseinstituttet, Nasjonalt kunnskapssenter om vold og traumatisk stress, rapport 8: Oslo, 2007.

Seto MC, Kjellgren C, Priebe G, Mossige S, Svedin CG, Långström N. Sexual victimization and sexual coercive behavior: A population study of Swedish and Norwegian male youth. Child Maltreatment 2010; 15: 219-228.

Smith DW, Letourneau EJ, Saunders BE, Kilpatrick DG, Resnick HS, Best CL. Delay in disclosure of childhood rape: Results from a national survey. Child Abuse \& Neglect 2000; 24: 273-287.

Svedin CG, Priebe G. Ungdomars sexualitet - attityder och erfarenheter. I: Statens offentliga utredningar, SOU 2004:71. Stockholm: Regjeringskanseliet, 2004.

Sætre M, Holter H, Jebsen E. Tvang til seksualitet. En undersøkelse av seksuelle overgrep mot barn. Oslo: J.W. Cappelens Forlag, 1986.

Tambs K. Undersøkelse av seksuelle overgrep mot barn. Statens Institutt for Folkehelse. Oslo, 1994.

Tolin DF, Foa E. Sex differences in trauma and posttraumatic stress disorder: A quantitative review of 25 years of research. Psychological Bulletin 2006; 132 (6): 959-992. 